\title{
PEMBERDAYAAN PETANI JAGUNG MELALUI PENGEMBANGAN USAHA DIVERSIFIKASI PRODUK OLAHAN JAGUNG DI LABUAPI KABUPATEN LOMBOK BARAT
}

\author{
Yeti Kurniasih $^{1}$, Citra Ayu Dewi ${ }^{2}$
}

\begin{abstract}
ABSTRAK
Secara umum masalah dan kendala utama yang dihadapi Petani Jagung di daerah Labuapi adalah belum adanya upaya dan pengembangan yang baik dalam usaha diversifikasi produk olahan jagung yang berdaya jual tinggi dan bernilai ekonomis. Kondisi ini dikarenakan masyarakat petani daerah Labuapi belum mengenal teknologi pengolahan tersebut. Selain itu, minat masyarakat terhadap pangan berbasis jagung masih rendah. Hal ini disebabkan oleh kurangnya pengetahuan sebagian masyarakat tentang nilai gizi jagung, tampilan produk pangan dari jagung yang kurang menarik, dan adanya anggapan bahwa jagung hanya dikonsumsi oleh masyarakat berekonomi lemah. Kegiatan KKN-PPM yang telah dilakukan ini bertujuan untuk meningkatkan keanekaragaman produk olahan jagung melalui penerapan teknologi pengembangan diversifikasi produk olahan jagung yang murah dan mudah diaplikasikan oleh petani jagung. Kegiatan KKN-PPM telah dilakukan selama 3 bulan pada semester genap tahun akademik 2016. Adapun kegiatan yang telah dilakukan meliputi: pembekalan KKN-PPM pada mahasiswa, pelatihan dan pendampingan secara langsung pada petani jagung dalam menghasilkan produk berupa diversifikasi olahan jagung seperti susu jagung, mie jagung, dodol jagung dan tempe jagung. Berdasarkan hasil pelatihan yang telah dilakukan didapatkan tingkat pemahaman dan keterampilan masyarakat (petani jagung) di Desa telagawaru memuaskan, sedangkan kualitas produk olahan jagung yang dihasilkan berhasil baik atau maksimal.
\end{abstract}

Kata Kunci: Diversifikasi, Produk Olahan Jagung.

\begin{abstract}
In general the problem and the main obstacle in the Corn Growers Labuapi area is the lack of effort and a good development in the processed product diversification efforts highly selling corn and economic value. This condition is due Labuapi local farming communities are not familiar with the processing technology. Moreover, public interest in the corn-based food is still low. This is caused by lack of knowledge of some people about the nutritional value of corn, corn display food products less attractive, and the assumption that maize is only consumed by the economically weak. KKN PPM activities that have been carried out aims to increase the diversity of corn refined products through the application of technology diversified development of corn processing products are cheap and easily applied by farmers maize. KKN-PPM have been conducted for 3 months in the second semester of the academic year 2016. The activities that have been undertaken include: increased KKN-PPM on the student, training and assistance directly to the corn farmers in the form of diversified products such as milk processed maize corn, noodles corn, corn and soybean corn dodol. Based on the results of the training has been done obtained a level of understanding and skills of the communities (farmers corn) in the village of telagawaru satisfactory, while the quality of the corn processed products produced successful or maximum.
\end{abstract}

${ }^{1}$ IKIP Mataram Jln. Pemuda No.59A Mataram, yeti_kurniasih2000@yahoo.com, 087865267226

${ }^{2}$ IKIP Mataram Jln. Pemuda No.59A Mataram 
Keywords: Diversification, Processed corn.

\section{PENDAHULUAN}

\subsection{Latar Belakang}

Jagung merupakan palawija sumber karbohidrat yang memegang peranan penting kedua setelah beras. Jagung juga mengandung unsur gizi lain yang diperlukan manusia yaitu kalori, dan protein. Dengan mengkonsumsi aneka macam produk olahan jagung, berarti telah melaksanakan program diversifikasi pangan non beras. Pengolahan jagung menjadi berbagai macam produk olahan, akan dapat meningkatkan nilai ekonomi dan nilai guna jagung sebagai bahan pangan non beras, disamping dapat meningkatkan pendapatan keluarga. Teknik pengolahannya dapat berasal dari jagung yang masih segar maupun yang telah kering (Purnomo dkk, 2012). Badan Pusat Statistik (BPS) mencatat bahwa produk unggulan sektor pertanian di daerah Labuapi adalah jagung dengan luas panen $3.296 \mathrm{Ha}$ dengan rata-rata produksi perhektar 32,79Kw/Ha. Dengan ketersediaan jagung yang sangat melimpah tersebut, tidak memberikan dampak yang berarti bila tidak diimbangi dengan peningkatan pendapatan petani. Hal ini dikarenakan, jagung akan cepat mengalami kerusakan jika tidak diberi perlakuan yang sebaik-baiknya setelah dipanen terutama jagung yang dipanen dalam usia yang masih muda. Sebagian besar produksi jagung di daerah ini hanya dijual dalam bentuk segar yang biasanya dipergunakan untuk direbus ataupun dijadikan sebagai sayuran dan sebagiannya lagi dikeringkan untuk dijadikan sebagai pakan ternak.

Secara umum masalah dan kendala utama yang dihadapi Petani Jagung di daerah Labuapi adalah belum adanya upaya dan pengembangan yang baik dalam usaha diversifikasi produk olahan jagung yang berdaya jual tinggi dan bernilai ekonomis. Kondisi ini dikarenakan masyarakat petani daerah ini belum mengenal teknologi pengolahan tersebut. Selain itu, minat masyarakat terhadap pangan berbasis jagung masih rendah. Hal ini disebabkan oleh kurangnya pengetahuan sebagian masyarakat tentang nilai gizi jagung, tampilan produk pangan dari jagung yang kurang menarik, dan adanya anggapan bahwa jagung hanya dikonsumsi oleh masyarakat berekonomi lemah. Maka dari itu, perlu dilakukan pengembangan usaha diversifikasi produk olahan jagung dengan keterpaduan berbagai aspek yang saling terkait satu sama lainnya, yaitu aspek produksi, aspek pengolahan, aspek pemasaran dan konsumsi. Oleh karena itulah peranan perguruan tinggi sebagai sumber tenaga ahli dan para peneliti sangat diperlukan.

Salah satu program yang sangat strategis mendukung kemitraan dalam bentuk pemberdayaan masyarakat petani jagung adalah melalui Kegiatan Program Pengabdian Kepada Masyarakat (KKN-PPM) dalam rangka penerapan teknologi tepat guna dengan maksud untuk meningkatkan kemampuan pasca panen masyarakat Labuapi pada tanaman jagung yaitu tanaman jagung menjadi produk diversifikasi bernutrisi dan bernilai jual tinggi, sehingga dapat membantu Pemerintah Daerah Kecamatan Labuapi dalam peningkatan pendapatan per kapita. Kebutuhan pangan selalu mengikuti trend jumlah penduduk dan dipengaruhi oleh perubahan pola konsumsi masyarakat. Ini menunjukkan indikasi bahwa diversifikasi pangan sangat diperlukan untuk mendukung pemantapan swasembada pangan. Melalui kegiatan KKN-PPM ini, jagung dapat dikembangkan menjadi produk olahan diversifikasi yang bernutrisi dan bernilai jual tinggi dibandingkan dengan bentuk segarnya, misalnya diolah menjadi tempe jagung, dodol jagung, susu jagung dan mie jagung yang tentunya akan mempunyai masa simpan lebih panjang jika dikemas dengan baik. Selain itu, dengan adanya diversifikasi olahan jagung menjadi berbagai produk diharapkan akan menambah deretan perbendaharaan hasil olahan jagung dan dapat meningkatkan konsumsi jagung untuk pangan. Hal ini tentunya akan memberikan multiplier

\section{4 | BULETIN UDAYANA MENGABDI}


effect bagi petani jagung, yaitu memberikan jaminan terserapnya produksi jagung oleh industri pangan dan meningkatnya pendapatan masyarakat petani jagung di daerah Labuapi.

\subsection{Tujuan Pengabdian}

Kegiatan KKN-PPM yang berjudul Pemberdayaan Petani Jagung melalui usaha pengembangan diversifikasi produk olahan jagung, ini ditujukan untuk meningkatkan keanekaragaman produk olahan jagung melalui penerapan teknologi pengembangan diversifikasi produk olahan jagung yang murah dan mudah diaplikasikan oleh petani jagung. Indikator capaian produk Program KKN-PPM yang dituju dalam kegiatan ini adalah:

a. Peningkatan produksi diversifikasi olahan jagung ditingkat petani jagung khususnya di daerah Kecamatan Labuapi, Kabupaten Lombok Barat.

b. Meningkatkan efisiensi biaya olahan jagung karena penggunaan teknologi pengembangan diversifikasi produk olahan jagung yang relatif murah dan mudah diaplikasikan oleh petani jagung.

c. Melakukan perbaikan pada sistem teknologi pengolahan jagung melalui pengembangan usaha diversifikasi produk olahan jagung guna meningkatkan nilai jual jagung.

d. Meningkatkan partisipasi masyarakat agar lebih bersemangat dalam melakukan diversifikasi produk olahan jagung.

e. Membangun kemitraan dan kerjasama yang efektif antara Perguruan Tinggi, Pemerintah Daerah dan masyarakat petani jagung di Kabupaten Lombok Barat.

\section{METODE PEMECAHAN MASALAH}

Metode Pemecahan masalah secara garis besar terbagi menjadi tiga bagian utama yaitu persiapan,pelaksanaan, serta evaluasi. Berikut uraian masing-masing kegiatan:

\subsection{Persiapan dan Pembekalan}

Pada tahap ini dosen pembimbing beserta beberapa perwakilan mahasiswa melakukan wawancara kepada aparat desa, masyarakat serta melakukan pertemuan langsung dengan petani jagung di Desa Telagawaru. Adapun tujuan dari pertemuan ini adalah untuk mengetahuiseberapa besar pengetahuan dan pemahaman masyarakat terhadap produk olahan jagung pasca panen dengan harapan teridentifikasilah permasalahan-permasalahan yang ada dimasyarakat. Dariidentifikasi masalah inilah muncul skala prioritas yang nantinya akan menjadi rencana kerja selama kegiatan KKN PPM. Pada tahap persiapan juga dilakukan pengurusan ijin-ijin yang berkaitan dengan kegiatan KKN PPM kepada instansi-instansi terkait. Setelah menyusun rencana kerja, maka dilakukanlah pembekalan kepada mahasiswa peserta KKN PPM yang nantinya mereka akan menjadi ujung tombak dilapangan. Pada pembekalan ini akan dilibatkan dosendosen maupun praktisi yang ahli dibidang masing-masing yang akan menunjang programprogram yang tertuang dalam rencana kerja.

\subsection{Tahapan Pelaksanaan Kegiatan}

Metode kegiatan KKN-PPM ini adalah metode workshop dalam bentuk pelatihan dan pendampingan secara intensif sampai menghasilkan produk berupa diversifikasi produk olahan jagung seperti tempe jagung, dodol jagung, susu jagung dan mie jagung. Kegiatan KKN-PPM ini direncanakan selama 3 bulan dan akan dilakukan pada Semester Genap Tahun Akademik 2016. Volume pekerjaan mahasiswa dalam bentuk Jam Kerja Efektif Mahasiswa (JKEM) sebanyak 18 JKEM.

\subsection{Rencana Keberlanjutan Program dan Evaluasi}

Dalam jangka panjang kegiatan pemberdayaan petani jagung melalui pengembangan usaha diversifikasi produk olahan jagung difasilitasi oleh KPRI.Budi Karya LPMP Mataram- 
NTB. Kegiatan peningkatan pengembangan diversifikasi produk olahan jagung dapat dilakukan terus-menerus dengan memasukkannya melalui kegiatan pengabdian kepada masyarakat yang dilakukan melalui kegiatan Kerja Nyata (KKN), sehingga dapat mengoptimalkan potensi mahasiswa setiap tahun. Keberlanjutan program telah dikomunikasikan dengan pihak KPRI. Budi Karya LPMP Mataram-NTB, sehingga dapat dilakukan secara luas dengan melibatkan Tim KKN-PPM IKIP Mataram dalam setiap kegiatan pelatihan dan pendampingan.Tindak lanjut kegiatan dilakukan melalui perluasan penerapan teknologi diversifikasi produk olahan jagung yang lebih beragam meliputi: es krim jagung, selai jagung, bakso jagung dan lain-lain. Dengan demikian teknologi yang sama dapat diaplikasikan pada pangan lokal yang lain. Keterlibatan masyarakat juga dapat terus diperluas, dengan melibatkan kelompok tani lainnya di seluruh Indonesia sehingga kebergantungan terhadap produk pangan ekspor berkurang.

\section{KELAYAKAN PERGURUAN TINGGI}

Tema KKN-PPM yang dicapai oleh Lembaga Penelitian dan Pengabdian Kepada Masyarakat (LPPM) IKIP Mataram melalui kegiatan KKN memberikan Pelatihan kepada masyarakat tentang berbagai hal diantaranya: (a) Pelatihan Pembuatan Perangkat Pembelajaran (b) Pembuatan pakan ikan dari limbah organik sisa pertanian (c) Pembuatan produk olahan dari ubi kayu (d) pengolahan limbah plastik menjadi bahan bakar di daerah lembar selatan (e) Pemberdayaan Masyarakat Daerah Wisata Gili Trawangan Lombok Berbasis CAEC (Community of Active English Communication). Dalam pelaksanaan kegiatan pengabdian pada masyarakat (PPM) yang kemudian diintegrasikan dengan kegiatan kuliah kerja nyata $(\mathrm{KKN})$ maka terjadilah akselerasi ketercapaian suatu program. Dalam jangka panjang untuk suatu seri Program KKN-PPM dengan tema Pemberdayaan masyarakat melalui kontribusi ilmiah berbasis Kuliah Kerja Nyata untukmeningkatkan keberdayaan masyarakat secara terukur, seperti; 1. Kenaikan income percapita melalui pelatihan kewirausahaan dan penelitian terapan yangsesuai dengan kebutuhan masyarakat, 2. Penurunan emisi $\mathrm{CO}_{2}$ melalui KKN-PPM da1am bidang konservasi lingkungan dan penyadaran masyarakat akan lingkungan hidup, 3. Peningkatan Indeks Pembangunan Manusia (IPM) melalui pendampingan dan pelatihan yang sistematis dan terukur, 4. Indeks Pembangunan Gender (IPG) melalui pelatihan dan pendampingan masyarakat Marjina dan mengurangi bias gender, 5. Penurunan angka kematian ibu melahirkan dan peningkatan umur harapan hidup melalui KKN-PPM bidang kesehatan.

\section{HASIL DAN PEMBAHASAN}

Kegiatan KKN PPM ini dilaksanakan di desa Telagawaru Kecamatan Labuapi Kabupaten Lombok Barat yang terdiri dari 3 dusun yaitu Dusun Telagawaru, Dusun Gubuq Aida, Dusun Paok Kambut. Kegiatan ini dimulai tanggal 13 Juni 2016 dan berakhir tanggal 15 September 2016. Rincian dari kegiatannya sebagai berikut:

\subsection{Persiapan dan Pembekalan KKN-PPM pada Mahasiswa}

Persiapan dimulai dengan memberikan pembekalan pada mahasiswa KKN PPM tentang materi-materi yang akan dilatihkan pada masyarakat serta praktek langsung terkait dengan diversifikasi produk olahan jagung antara lain: Pengantar tentang komposisi kimia, kandungan nutrisi dan unsur pangan fungsional (nilai tambah) pada jagung, Pengantar proses tahapan dalam pengembangan usaha diversifikasi produk olahan jagung, Pelatihan dan praktek langsung dalam diversifikasi produk olahan jagung pada pembuatan susu, Pelatihan dan praktek langsung dalam diversifikasi produk olahan jagung pada pembuatan dodol, Pelatihan dan praktek langsung dalam diversifikasi produk olahan jagung pada pembuatan mie, Pelatihan dan praktek langsung dalam diversifikasi produk olahan jagung pada pembuatan tempe.

\subsection{Koordinasi Tim Pengabdi dengan Pihak Desa}


Setelah mahasiswa dibekali dengan cara pengolahan produk jagung, mereka mempersiapkan perlengkapan untuk tinggal di desa beserta perijinannya. Sementara tim pengabdi melakukan koordinasi dengan kepala desa tanggal 23 juli 2016 terkait program KKN-PPM yang dilaksanakan serta merencanakan acara pelepasan mahasiswa KKN-PPM ke Desa Telagawaru. Acara pelepasan dan berangkat ke desa bersama-sama dosen pembimbing lapangan dilaksanakan pada tanggal 01 agustus 2016. Tiba di Desa langsung disambut oleh Kepala Desa beserta semua stafnya. Selesai acara pelepasan, mahasiswa langsung ditempatkan di Posko yang sudah tersedia. Selama 3 hari digunakan untuk observasi dan sosialisasi program. Dari hasil observasi dapat diketahui kondisi lokasi yang akan digunakan untuk melakukan kegiatan, dan dari hasil sosialisasi program dapat diketahui pemahaman masyarakat terhadap kegiatan KKN-PPM.

\subsection{Pelaksanaan Kegiatan}

Kegiatan dimulai dengan mengadakan pelatihan pada masyarakat tentang diversifikasi produk olahan jagung. Pelatihan diberikan teorinya terlebih dahulu, kemudian diteruskan dengan simulasi olahan jagung. Selanjutnya praktek langsung diversifikasi produk olahan jagung pada masyarakat petani jagung dengan bimbingan mahasiswa. Pelatihan dilaksanakan setiap hari dengan waktu pelaksanaan sesuai kesepakatan bersama.

\subsection{Evaluasi Kegiatan}

Untuk mengetahui tingkat pemahaman dan keterampilan masyarakat dalam diversifikasi produk olahan jagung, maka evaluasi dilaksanakan saat proses simulasi dan praktek berlangsung (evaluasi proses) sedangkan evaluasi produk dilakukan setelah produk olahan jagung dihasilkan berupa uji organoleptik. Evaluasi proses berupa kegiatan partisipatif bersama masyarakat terkait dengan keterampilan masyarakat dalam pelatihan diversifikasi produk olahan jagung. Berdasarkan hasil evaluasi menunjukkan bahwa pemahaman dan keterampilan masyarakat memuaskan sedangkan kualitas produk yang dihasilkan berhasil baik atau maksimal.

\section{SIMPULAN DAN SARAN}

Dari kegitan yang telah dilakukan selama 3 (tiga) bulan maka kegiatan KKN PPM ini dapat dikatakan berhasil dengan baik, ada beberapa saran yang dapat disampaikan yaitu untuk KKN PPM periode mendatang hendaknya melanjutkan program pendampingan, pemeliharaan dan monitoring dalam rangka sustainaibility program bagi masyarakat dalam diversifikasi produk olahan jagung.

\section{UCAPAN TERIMA KASIH}

Ucapan terima kasih disampaikan kepada:

1. Direktorat Riset dan Pengabdian kepada Masyarakat, Direktorat Jenderal Penguatan Riset dan Pengembangan Kementerian Riset, Teknologi, dan Pendidikan Tinggi atas bantuannya dalam mendanai kegiatan pegabdian ini.

2. LPPM IKIP Mataram atas bantuannya dari aspek manajemen sehingga kegiatan ini dapat dilaksanakan.

\section{DAFTAR PUSTAKA}

Badan Pusat Statistik. (2015). Statistik Indonesia. Statistics Indonesia and Directorat General of Foodcrops. Lombok Barat-NTB.

Purnomo, E. H., Sitanggang, A. B., Agustin, D. S., Hariyadi, P., \& Hartono, S. (2012). Formulation and Process Optimization of Muffin Produced From Composite Flour of Corn, Wheat and Sweet Potato. Journal of Agriculture and Science Technology: XXIII(2), 165172. doi:10.6066/jtip.2012.23.2.165.

Soekarto, S.T. (2010). Penelitian Organoleptik untuk Industrik Pangan dan Hasil Pertanian. Liberty. Yogyakarta. 
Pemberdayaan Petani Jagung Melalui Pengembangan Usaha Diversifikasi Produk Olahan Jagung Di Labuapi Kabupaten Lombok Barat 